\title{
Effects of disodium malate on microbial growth and rumen fermentation of two diets in Rusitec fermenters*
}

\author{
J.A. Gómez, M.L. Tejido and M.D. Carro ${ }^{1}$ \\ Departamento de Producción Animal I, Universidad de León \\ 24071 León, Spain
}

\begin{abstract}
The objective of this study was to investigate the effects of disodium malate $(6.65 \mathrm{mM})$ on the in vitro fermentation of two diets (F ( $40 \%$ concentrate) and $\mathrm{C}(90 \%$ concentrate)). Malate treatment increased $(\mathrm{P}<0.001)$ dry matter and neutral-detergent fibre disappearance with both diets. Daily production of propionate and butyrate increased $(\mathrm{P}<0.001)$ and the ratio $\mathrm{CH}_{4}$ :VFA decreased $(\mathrm{P}<0.001)$ by adding malate for both diets. Whereas adding malate to $\mathrm{F}$ diet produced an increase $(\mathrm{P}<0.05)$ in acetate production, this effect was not observed with $\mathrm{C}$ diet. In addition, malate treatment increased $(\mathrm{P}<0.05)$ the daily growth of solid-associated bacteria with $\mathrm{F}$ diet, but no effects $(\mathrm{P}>0.05)$ were detected with $\mathrm{C}$ diet. The results seem to indicate that disodium malate stimulated the in vitro fermentation of both diets, but a greater response was observed with diet $\mathrm{F}$.
\end{abstract}

KEYWORDS: malate, Rusitec, rumen fermentation, microbial growth

\section{INTRODUCTION}

Organic acids (aspartate, malate, fumarate) have been suggested as an alternative to currently used antibiotic growth promoters. Several papers (Callaway and Martin, 1996; Carro et al., 1999; Carro and Ranilla, 2003) have shown that adding malate to in vitro fermentations of mixed rumen micro-organisms resulted in changes in final $\mathrm{pH}, \mathrm{CH}_{4}$ and volatile fatty acids (VFA) that are analogous to ionophore effects. However, results of some of these studies (Carro and Ranilla, 2003) indicate that effects of malate are affected by composition of the incubated diet. In addition, most of these studies have been conducted in short term experiments (incubations up to $24 \mathrm{~h}$ ) using batch cultures of mixed rumen micro-organisms, and little is known about longer term effects of malate on in vitro rumen fermentation and microbial growth. Therefore, the aim of this study

\footnotetext{
* Supported by M.C.Y.T. of Spain, Project AGL2001-0130 and Junta de Castilla y León (Project LE62/03

${ }^{1}$ Corresponding author: e-mail: DP1MCT@UNILEON.ES
} 
was to investigate the effects of disodium malate on microbial growth and rumen fermentation of two different diets in Rusitec fermenters.

\section{MATERIAL AND METHODS}

The study was carried out using the rumen simulation technique Rusitec. The complete unit consisted of eight vessels with an effective volume of $600 \mathrm{ml}$ each. The vessels inoculum (solid and liquid) was obtained from three ruminally fistulated ewes fed a diet consisting of lucerne hay and concentrate (50:50). The flow through the vessels was maintained by continuous infusion of artificial saliva at a rate of $550 \mathrm{ml} / \mathrm{d}$. Two identical 14 days incubation trials were carried out independently, and treatments were assigned randomly within each experimental run so that two vessels received each treatment. The dietary treatments consisted of two complete diets composed of rye-grass and concentrate in the proportion of 60:40 (diet F), and of barley straw and concentrate in the proportion of 10:90 (diet C). Crude protein and neutral-detergent fibre (NDF) content of diets was 177 and $287 \mathrm{~g} / \mathrm{kg} \mathrm{DM}$ for diet F, and 161 and $220 \mathrm{~g} / \mathrm{kg}$ for diet C. Each vessel received daily $20 \mathrm{~g}$ of dry matter (DM) of the corresponding diet. Diets were administered either with or without $3.93 \mathrm{mmol} / \mathrm{d}(6.65 \mathrm{mM})$ of disodium malate (Sigma-Aldrich Química, S.A., Spain) from the first day of the experiment.

After 9 days adaptation period, the $\mathrm{pH}$ and the production of $\mathrm{CH}_{4}$ and VFA were measured in each vessel on 3 consecutive days. Every day one nylon bag that had spent $48 \mathrm{~h}$ in the vessel was removed and a new bag with food was introduced in each vessel. Each bag was washed twice with $40 \mathrm{ml}$ artificial saliva and then washed in the cold rinse cycle (20 min) of a washing machine. DM disappearance was calculated from the loss in weight after oven drying at $60^{\circ} \mathrm{C}$ for $48 \mathrm{~h}$, and the residues were analysed for neutral-detergent fibre (NDF). From day 9 to the end of the experiment, a solution of $95 \%$ enriched $\left({ }^{15} \mathrm{NH}_{4}\right)_{2} \mathrm{SO}_{4}$ was added to the artificial saliva as a microbial marker. On days 13 and 14, nylon bag residues and effluent from each vessel were taken to determine the growth of solid-associated bacteria $(\mathrm{SAB})$ and liquid-associated bacteria (LAB) following the procedures described by Carro and Miller (1999).

Data were analysed as a split-plot design with malate treatment and incubation trial as the main-plot treatments and diet as the subplot treatment. Effect of malate on any of the considered variables was tested using the variance between vessels within treatment as the error term. Effects of diet, incubation trial and the interaction of diet $\times$ malate treatment were tested against the residual error. The GLM procedures of SAS (SAS Inst., Inc., Cary, NC) were used for all statistical analyses.

\section{RESULTS AND DISCUSSION}

The coefficient of variation of the parameters measured in consecutive days was small and fairly constant for each of the treatments. The effects of malate on the 
measured parameters are shown in Table 1. Malate treatment produced an increase $(\mathrm{P}<0.001)$ in DM and NDF disappearance with both diets. In agreement with these results, Newbold et al. (1996) reported a trend towards a higher disappearance of hay DM from nylon bags incubated for $48 \mathrm{~h}$ in the rumen of sheep supplemented with $100 \mathrm{mg}$ of malic acid per day (51 vs 55\%). Moreover, Carro et al. (1999) found that adding $7.5 \mathrm{mM}$-malate to Rusitec fermenters increased $(\mathrm{P}<0.05)$ hemicellulose disappearance with a 50:50 forage:concentrate diet.

Table 1. Influence of adding malate $(3.93 \mathrm{mmol} / \mathrm{d})$ to Rusitec fermenters fed two diets of different composition on $\mathrm{pH}, \mathrm{CH}_{4}$ and volatile fatty acid (VFA) production, disappearance of dry matter (DMD) and neutral-detergent fibre (NDFD), as well as daily growth of solid- (SAB) and liquidassociated bacteria (LAB)

\begin{tabular}{|c|c|c|c|c|c|c|c|c|}
\hline \multirow{2}{*}{ Indices } & \multicolumn{2}{|c|}{ Diet F } & \multicolumn{2}{|c|}{ Diet C } & \multirow{2}{*}{ SED } & \multicolumn{3}{|c|}{$\begin{array}{l}\text { Statistical significance of } \\
\text { the treatment effect }(\mathrm{P}=)\end{array}$} \\
\hline & control & malate & control & malate & & $\begin{array}{c}\text { malate } \\
\text { diet }\end{array}$ & diet & $\begin{array}{l}\text { malate } \\
\times \text { diet }\end{array}$ \\
\hline $\mathrm{pH}$ & 6.32 & 6.33 & 5.90 & 5.89 & 0.015 & NS & 0.001 & NS \\
\hline $\mathrm{CH}_{4}, \mathrm{mmol} / \mathrm{d}$ & 12.6 & 12.1 & 13.1 & 12.8 & 0.42 & NS & NS & NS \\
\hline \multicolumn{9}{|l|}{$V F A, \mathrm{mmol} / \mathrm{d}$} \\
\hline acetate & 28.8 & 31.8 & 40.3 & 40.8 & 1.16 & NS & 0.001 & NS \\
\hline propionate & 6.95 & 9.40 & 7.88 & 10.3 & 0.27 & 0.001 & 0.001 & NS \\
\hline butyrate & 9.21 & 10.2 & 13.1 & 15.1 & 0.36 & 0.001 & 0.001 & $\mathrm{NS}^{\S}$ \\
\hline isobutyrate & 0.828 & 0.793 & 0.827 & 0.852 & 0.0766 & NS & NS & NS \\
\hline isovalerate & 1.38 & 1.53 & 1.84 & 2.21 & 0.077 & 0.049 & 0.001 & NS \\
\hline valerate & 3.05 & 3.50 & 3.17 & 3.76 & 0.089 & 0.007 & 0.013 & NS \\
\hline total VFA & 50.2 & 57.2 & 67.1 & 73.0 & 1.54 & 0.044 & 0.001 & NS \\
\hline $\mathrm{CH}_{4}: \mathrm{VFA}$ & 0.251 & 0.212 & 0.195 & 0.175 & 0.0081 & 0.012 & 0.001 & NS \\
\hline DMD, $\%$ & 62.0 & 65.6 & 63.5 & 66.8 & 0.90 & 0.001 & 0.001 & NS \\
\hline NDFD, $\%$ & 28.5 & 34.2 & 21.0 & 27.9 & 1.17 & 0.001 & 0.001 & NS \\
\hline \multicolumn{9}{|l|}{ Microbial growth } \\
\hline $\mathrm{SAB}, \mathrm{mg} \mathrm{N} / \mathrm{d}$ & 54.1 & 67.4 & 40.3 & 42.2 & 1.89 & 0.019 & 0.001 & $\mathrm{NS}^{\S}$ \\
\hline $\mathrm{LAB}, \mathrm{mg} \mathrm{N} / \mathrm{d}$ & 71.7 & 72.3 & 83.7 & 86.7 & 2.56 & NS & 0.015 & NS \\
\hline $\begin{array}{c}\text { total } \\
(\mathrm{SAB}+\mathrm{LAB})\end{array}$ & 125.8 & 139.7 & 124.0 & 128.9 & 2.53 & $\mathrm{NS}^{\S}$ & NS & NS \\
\hline
\end{tabular}

NS - $\mathrm{P}>0.05 ; \mathrm{NS}^{\S} \mathrm{P}<0.10$

Differences in the amount of feed degraded could result in differences in VFA production. Malate treatment increased $(\mathrm{P}<0.001)$ propionate and butyrate production with both diets, but acetate production was only increased $(\mathrm{P}<0.05)$ with diet $\mathrm{F}$. Addition of malate produced similar increases of propionate production for both diets ( 2.45 and $2.42 \mathrm{mmol} / \mathrm{d}$ for diets $\mathrm{F}$ and $\mathrm{C}$, respectively), but whereas acetate production was increased by $3.04 \mathrm{mmol} / \mathrm{d}$ for diet $\mathrm{F}$, the increase was only $0.53 \mathrm{mmol} / \mathrm{d}$ for diet $\mathrm{C}$. These results agree with those from Carro and Ranilla (2003) who found that malate utilization in vitro (batch cultures) could depend on the incubated substrate. 
Differences in the VFA production could result in differences in ruminal $\mathrm{pH}$, as there is no absorption in RUSITEC. However, there were no differences $(\mathrm{P}>0.05)$ due to malate addition in the $\mathrm{pH}$ of the vessels liquor. Some authors (Martin and Streeter, 1995; Carro and Ranilla, 2003) reported an increase in rumen $\mathrm{pH}$ by adding malate to concentrate diets in batch cultures, but Carro et al. (1999) did not find an effect $(\mathrm{P}>0.05)$ of malate on rumen $\mathrm{pH}$ in Rusitec fermenters fed a 50: 50 forage:concentrate diet. These contrasting results could be due to the different buffer solutions used in the two systems.

Some previous studies (Callaway and Martin, 1996; Carro and Ranilla, 2003) have reported a decrease in $\mathrm{CH}_{4}$ formation when adding similar doses of malate to in vitro cultures of rumen mixed micro-organisms. In the present experiment malate did not affect $(\mathrm{P}>0.05) \mathrm{CH}_{4}$ production, but the ratio $\mathrm{CH}_{4}: \mathrm{DM}$ degraded $(\mathrm{mmol} / \mathrm{g})$ was decreased $(\mathrm{P}<0.001)$ by adding malate for both diets.

Malate treatment increased $(\mathrm{P}<0.05)$ the daily growth of $\mathrm{SAB}$ with $\operatorname{diet} \mathrm{F}(54.1 \mathrm{vs}$ $67.4 \mathrm{mg}$ bacterial $\mathrm{N} / \mathrm{d})$ but no effects $(\mathrm{P}>0.05)$ were detected with $\mathrm{C}$ diet. These results agree with those obtained in some previous studies conducted in our laboratory, which showed that malate stimulated microbial growth in batch cultures of mixed rumen micro-organisms with a 80:20 forage:concentrate diet, but no effect was detected with a 20:80 forage:concentrate diet (unpublished results). No effects $(\mathrm{P}>0.05)$ of malate on daily growth of $\mathrm{LAB}$ were detected. These results would indicate that effects of malate on in vitro rumen fermentation could depend on the incubated substrate. More studies are required to assess the dietary conditions that influence the effectiveness of malate.

\section{CONCLUSIONS}

The results seem to indicate that malate stimulated the in vitro fermentation of the two diets by increasing diet disappearance and VFA production, but these effects were more marked for the F diet.

\section{REFERENCES}

Callaway T.R., Martin S.A., 1996. Effects of organic acid and monensin treatment on in vitro mixed ruminal microorganism fermentation of cracked corn. J. Anim. Sci. 74, 1982-1989

Carro M.D., Miller E.L., 1999. Effect of supplementing a fibre basal diet with different nitrogen forms on ruminal fermentation and microbial growth in an in vitro semicontinuous culture system (RUSITEC). Brit. J. Nutr. 82, 149-157

Carro M.D., López S., Valdés C., Ovejero F.J., 1999. Effect of DL-malate on mixed ruminal microorganism fermentation using the rumen simulation technique (RUSITEC). Anim. Feed Sci. Tech. 79, 279-288

Carro M.D., Ranilla M.J., 2003. Effect of the addition of malate on in vitro rumen fermentation of cereal grains. Brit. J. Nutr. 89, 279-288

Martin S.A., Streeter M.N., 1995. Effect of malate on in vitro mixed ruminal microorganism fermentation. J. Anim. Sci. 73, 2141-2145

Newbold C.J., Wallace R.J., McIntosh F.M., 1996. Mode of action of the yeast Saccharomyces cerevisiae as a feed additive for ruminants. Brit. J. Nutr. 76, 249-261 